\title{
Chemical Composition, Starch Digestibility and Antioxidant Capacity of Tortilla Made with a Blend of Quality Protein Maize and Black Bean
}

\author{
Eva M. Grajales-García ${ }^{1}$, Perla Osorio-Díaz ${ }^{1, *}$, Isabel Goñi ${ }^{2}$, Deisy Hervert-Hernández ${ }^{2}$, \\ Salvador H. Guzmán-Maldonado ${ }^{3}$ and Luis A. Bello-Pérez ${ }^{1}$
}

1 Centro de Desarrollo de Productos Bióticos del IPN, Km 8.5 carr, Yautepec-Jojutla, Colonia San Isidro, Apartado postal 24, Yautepec, Morelos 62731, Mexico; E-Mails: evamariagg05@hotmail.com (E.M.G.-G.); labellop@ipn.mx (L.A.B.-P.)

2 Departamento de Nutrición, Facultad de Farmacia, Universidad Complutense de Madrid, Ciudad Universitaria, Madrid 28040, Spain; E-Mails: igonic@farm.ucm.es (I.G.); deisy_hervert@hotmail.com (D.H.-H.)

3 Unidad de Biotecnología del Campo Experimental Bajío (INIFAP), Km 6.5 Celaya, San Miguel de Allende S/N, Celaya, Guanajuato 38110, Mexico; E-Mail: guzman.horacio@inifap.gob.mx

* Author to whom correspondence should be addressed; E-Mail: posorio@ipn.mx; Tel.: +52-735-3942020; Fax: +52-735-3941896.

Received: 6 October 2011; in revised form: 4 December 2011 / Accepted: 14 December 2011 / Published: 27 December 2011

\begin{abstract}
Tortilla and beans are the basic components in the diet of people in the urban and rural areas of Mexico. Quality protein maize is suggested for tortilla preparation because it presents an increase in lysine and tryptophan levels. Beans contain important amounts of dietary fiber. The objective of this study was to prepare tortilla with bean and assesses the chemical composition, starch digestibility and antioxidant capacity using a quality protein maize variety. Tortilla with bean had higher protein, ash, dietary fiber and resistant starch content, and lower digestible starch than control tortilla. The hydrolysis rate (60 to $50 \%$ ) and the predicted glycemic index ( 88 to 80 ) of tortilla decreased with the addition of bean in the blend. Extractable polyphenols and proanthocyanidins were higher in the tortilla with bean than control tortilla. This pattern produced higher antioxidant capacity of tortilla with bean $(17.6 \mu \mathrm{mol}$ Trolox eq/g) than control tortilla $(7.8 \mu \mathrm{mol}$ Trolox eq/g). The addition of bean to tortilla modified the starch digestibility and antioxidant characteristics of tortilla, obtaining a product with nutraceutical characteristics.
\end{abstract}


Keywords: tortilla; bean; starch digestibility; antioxidant capacity; chemical composition

\section{Introduction}

Maize (Zea mays L.) is used in the production of tortilla, which is the principal staple food in the Mexican diet [1,2]. In the rural areas of Mexico, tortilla per capita consumption is higher than $120 \mathrm{~kg} / \mathrm{year}$, which is equivalent to $328 \mathrm{~g} /$ day [3]. It is known that maize is deficient in lysine and tryptophan, two essential amino acids. Quality protein maize (QPM) can be an alternative to improve the nutritional quality of tortilla, which was developed from opaque2 maize. QPM shows higher lysine (3.4-6.0 g/100 g of protein) and tryptophan (0.8-1.2 g/100 g of protein) content than regular maize [4].

The common bean (Phaseolus vulgaris L.) has an important place among the legumes of major production and consumption in Africa, India, Latin America, and Mexico [5-7]. In the rural areas of Mexico, consumption of beans represents $15 \%$ of a normal diet [8]. In consequence, common bean and maize represent the main food source for more than 25 million Mexican people who live in rural areas, as well as for 30 million people who live in marginal urban areas [9]. Beans are a rich and inexpensive source of proteins $(20-25 \mathrm{~g} / 100 \mathrm{~g})$ and carbohydrates $(50-60 \mathrm{~g} / 100 \mathrm{~g})$ [10] and they are beneficial for health, with a low glycemic index [11]. Recently, our group reported the antioxidant capacity of three legumes consumed in Mexico. It was found that black bean had the greatest concentration of proanthocyanidins (an outstanding antioxidant) [12].

Traditionally, people in the rural areas of Mexico and Central America consume a mixture of tortilla, beans, and chili, often named "taco" [13]. It is well-known that such a mixture improves some of the nutritional characteristics of the individual items, especially on the nutritionally relevant features of the polysaccharides present in this composite food [13]. Results from our group suggested that most of the beneficial "slow release carbohydrate" features of black beans are retained by the mixed bean-tortilla meal, an observation that may provide basis for new dietary uses of these traditional foods [14].

However, the blend "masa" and cooked bean flour, for thereafter-made tortilla has not been studied in its starch digestibility and antioxidant capacity. Mora-Avilés et al. [15] prepared tortilla with the blend QPM and bean, and evaluated the amino acids and mineral changes that occur during nixtamalization and the chemical and nutritional characteristics of regular, commercial and QPM-bean tortilla.

Therefore, the objective of the present work was to assess the chemical composition, digestibility of starch and antioxidant capacity in tortilla prepared with the blend QPM-black bean compared to that of individual ingredients.

\section{Results and Discussion}

\subsection{Chemical Composition}

Chemical composition of raw materials and tortillas is shown in Table 1. When QPM is nixtmalized to produce "masa" and tortilla, the protein does not change appreciably. An increase of $37 \%$ in protein 
content in QPM-black bean tortilla was found compared to that of QPM tortilla. Our results for the protein content of QPM-black bean tortilla were higher compared to those previously reported by Hernández-Salazar et al. [16], who indicated that a tortilla prepared with maize-bean showed $10.5 \mathrm{~g} / 100 \mathrm{~g}$; however, they did not declare the maize-bean blend used. Black dry bean characterized by high protein content, shows between 18.9 and $24.2 \mathrm{~g} / 100 \mathrm{~g}$ [17]. The presence of black bean in tortilla reported in this work was responsible for increments in protein. On the other hand, maize shows lower protein level than beans. Diverse hybrids and varieties of maize harvested in México had protein content between 8.3 and $11.3 \mathrm{~g} / 100 \mathrm{~g}$, with higher amount in dent and semident type grains than in crystalline and semicrystalline grains [18]. When maize is nixtamalized to produce "masa" $(8.7 \mathrm{~g} / 100 \mathrm{~g})$ and tortilla $(7.5 \mathrm{~g} / 100 \mathrm{~g})$, the protein does not change appreciably compare with raw maize [19]. Maize shows higher fat (6.6 g/100 g) content [19] than dry beans (1.3 and $2.8 \mathrm{~g} / 100 \mathrm{~g})$ [17] due to germ of the former (Table 1). Meanwhile, "masa" showed $3.1 \mathrm{~g} / 100 \mathrm{~g}$ and tortilla of $2.5 \mathrm{~g} / 100 \mathrm{~g}$ of fat content due to that during nixtamalization fat was eliminated in the "nejayote" [19]. Fat content in "masa" an tortilla reported previously was lower to those reported here [19]. The maize utilized here can play an important role in our results; hybrids and varieties of maize [18] had fat content between 4 and $7 \mathrm{~g} / 100 \mathrm{~g}$, and commercial white tortilla had a fat content of $3 \mathrm{~g} / 100 \mathrm{~g}$ [16]. Initially, the expression of the opaque 2 gene increased the content of essential amino acids in maize but was also associated with lower per-acre yields, increased susceptibility to pests and diseases, and a soft endosperm, which made it unacceptable to many potential users. Currently, QPM which is high-yielding, disease- and parasite-resistant, and has a brittle endosperm but retains the superior amino acid balance of opaque2, was achieved through the introduction of gene modifiers. These characteristics can be bred into traditional, locally adapted varieties anywhere that maize is grown [20], so, as well as in common maize varieties, the differences in fat content of QPM varieties can be depending on the variety [18,20], and in tortillas, the differences in fat content may be also attributable to maize variety and conditions prevailing during nixtamalization process [21]. QPM-black bean tortilla reported here had similar fat content than tortilla, this pattern is due to that in the blend the amount of maize is higher and no dilution effect was found.

Table 1. Chemical composition of black bean flour, quality protein maize (QPM) masa, QPM tortilla and QPM-black bean tortilla (g/100 g).

\begin{tabular}{ccccc}
\hline Sample & Protein $^{*}$ & Fat & Ash & TDF \\
\hline Black bean flour & $21.45 \pm 0.36 \mathrm{a}$ & $1.24 \pm 0.03 \mathrm{a}$ & $4.66 \pm 0.02 \mathrm{a}$ & $36.24 \pm 0.70 \mathrm{a}$ \\
QPM masa & $7.89 \pm 0.11 \mathrm{~b}$ & $5.03 \pm 0.22 \mathrm{~b}$ & $1.61 \pm 0.02 \mathrm{~b}$ & $8.55 \pm 0.41 \mathrm{~b}$ \\
QPM tortilla & $8.78 \pm 0.06 \mathrm{~b}$ & $4.37 \pm 0.23 \mathrm{bc}$ & $1.67 \pm 0.00 \mathrm{~b}$ & $9.36 \pm 0.27 \mathrm{~b}$ \\
QPM-black bean tortilla & $12.04 \pm 0.43 \mathrm{c}$ & $3.89 \pm 0.25 \mathrm{c}$ & $2.58 \pm 0.01 \mathrm{c}$ & $14.72 \pm 0.30 \mathrm{c}$ \\
\hline
\end{tabular}

Values are mean \pm SEM, $n=3$, dry matter. Means in the same column with different letter are significantly different $(\mathrm{p}<0.05)$. TDF: Total dietary fiber. ${ }^{*} \mathrm{~N} \times 6.25$.

Ash content in black bean was higher than in "masa" and tortillas (Table 1). In general, legumes are characterized by high minerals levels, which depend on the species, cultivar, and agronomic characteristics (soil type). Black bean [22] had an ash content of $5.4 \mathrm{~g} / 100 \mathrm{~g}$ and different varieties of black bean harvested in Mexico ranged between 3.6 to $5.2 \mathrm{~g} / 100 \mathrm{~g}$ [17]. Maize has low ash content as was reported in diverse hybrids and cultivars $(1.1-1.7 \mathrm{~g} / 100 \mathrm{~g})$ [18]. Tortilla prepared in our laboratory 
shows an ash content of $1.6 \mathrm{~g} / 100 \mathrm{~g}$ [19], meanwhile commercial white tortilla showed $1.9 \mathrm{~g} / 100 \mathrm{~g}$ [16]. However, the QPM-black bean tortilla increased its ash contents $(2.58 \mathrm{~g} / 100 \mathrm{~g})$ due to the contribution of the bean. Similar pattern was reported in tortilla prepared with white maize flour $(1.88 \mathrm{~g} / 100 \mathrm{~g})$ and maize-bean flour $(2.95 \mathrm{~g} / 100 \mathrm{~g})$ [16].

Total dietary fiber (TDF) content was higher in QPM-black bean tortilla compared to that of QPM masa and QPM tortilla (Table 1). Black bean showed the highest TDF level. Beans are characterized by a high content of this component. In two different beans (Navy and Red) the TDF contents were 36.2 and $36.8 \mathrm{~g} / 100 \mathrm{~g}$, respectively [23]. Reynoso-Camacho et al. [24] reported that the addition of common bean in the diets reduced colon cancer in Sprage-Dawley rats, and this pattern was influenced by the dietary fiber content. There were no differences between content of TDF of QPM "masa" and QPM tortilla; meanwhile, QPM-black bean tortilla showed higher value than QPM tortilla. The addition of bean in the blend increases this nutritional component in tortilla in 57\%, an important issue due to that black bean tortilla could be considered as a functional food.

\subsection{Starch Digestibility}

Black bean showed the lowest, and "masa" and tortilla the highest total starch (TS) levels (Table 2). Black bean varieties harvested in Mexico shows TS between 33.6 and $36.7 \mathrm{~g} / 100 \mathrm{~g}$ [17]; in another study, cooked black bean showed a TS content of $53.8 \mathrm{~g} / 100 \mathrm{~g}$ [22], which was higher than those assessed here, the bean variety can be responsible of this difference. On the other hand, total starch level in masa and tortilla was similar. It has been reported that tortillas elaborated with commercial dry masa flour shows TS content between 76.2 and $79.0 \mathrm{~g} / 100 \mathrm{~g}$ [25], and those elaborated with commercial masa between 74.8 and $79.7 \mathrm{~g} / 100 \mathrm{~g}$ [21], values similar to those reported in this study. Black bean tortilla had lower TS content than tortilla, this effect is due to dilution produced by addition of black bean with lower TS content. Similar TS content $(65.6 \mathrm{~g} / 100 \mathrm{~g})$ was determined in commercial maize-bean tortilla [16].

Table 2. Total starch, digestible starch and resistant starch in black bean flour, quality protein maize (QPM) masa, QPM tortilla and QPM-black bean tortilla (g/100 g).

\begin{tabular}{|c|c|c|c|}
\hline Sample & Total starch & Digestible starch $^{*}$ & Resistant starch \\
\hline Black bean flour & $44.36 \pm 0.52 \mathrm{a}$ & $37.92 \pm 0.55 \mathrm{a}$ & $6.44 \pm 0.07 \mathrm{a}$ \\
\hline QPM masa & $77.68 \pm 0.20 b$ & $74.50 \pm 0.20 b$ & $3.17 \pm 0.01 \mathrm{~b}$ \\
\hline QPM tortilla & $76.69 \pm 0.82 b$ & $71.65 \pm 0.80 \mathrm{c}$ & $5.04 \pm 0.05 \mathrm{c}$ \\
\hline QPM-black bean tortilla & $66.75 \pm 0.47 \mathrm{c}$ & $60.45 \pm 0.48 \mathrm{~d}$ & $6.30 \pm 0.08 \mathrm{a}$ \\
\hline
\end{tabular}

Values are mean \pm SEM, $n=3$, dry matter. Means in the same column with different letter are significantly different $(p<0.05)$. Values calculated as the difference between total starch and resistant starch.

TS content is in tune with digestible starch (DS) amount recorded in the samples analyzed (Table 2). Low DS content, as was assessed in different cooked dry bean varieties harvested in Mexico, with values ranged between 21.7 and $32.2 \mathrm{~g} / 100 \mathrm{~g}$ [26]. However, it has been reported a higher range of DS values in cooked beans (27.88-39.21 g/100 g) [27], suggesting that the cooking method, the storage and perhaps the dry bean variety play an important role in DS content, a value within this range was 
determined here. QPM "masa" shows the highest DS content, decreasing in QPM tortilla (Table 2). This decrease could be due to the fact that the starch of masa was partially gelatinized and part of this was retrograded when the tortilla was cooling down. The formation of retrograded starch requires dehydration of the gelatinized sample [28,29], a phenomenon that is likely to take place when tortillas are baked at $\approx 250{ }^{\circ} \mathrm{C}$ and cooled. Rendon-Villalobos et al. [19] reported a similar pattern, with higher DS value in "masa" $(79.6 \mathrm{~g} / 100 \mathrm{~g})$ than tortilla $(72.9 \mathrm{~g} / 100 \mathrm{~g})$. In addition, a similar value of DS for tortilla made with commercial "masas" was reported (70.1-76.0 g/100 g) [21], and those made with commercial dry masa flour (70.6-74.9 g/100 g) [25]. Tortilla prepared with commercial white maize flour $(63.5 \mathrm{~g} / 100 \mathrm{~g})$ [16] and commercial tortilla $(65.2 \mathrm{~g} / 100 \mathrm{~g})$ [13] had lower DS content. The addition of bean to tortilla decreased DS content in approximately $15.6 \%$, this pattern due to the amount of bean added and the lower DS level in this legume. Mexican "taco" [13] (a mixture of tortilla and bean 60:40) was studied in its DS content, showing a DS content of $52.6 \mathrm{~g} / 100 \mathrm{~g}$; the ratio maiz:bean and the method utilized for the preparation of the samples could explain such differences. In commercial maize-bean tortilla DS content of $60.3 \mathrm{~g} / 100 \mathrm{~g}$ was reported, but the ratio maize-bean is not declared [16].

Black bean showed the highest resistant starch (RS) content and was similar to that of QPM-black bean tortilla. RS contents between 3.5 and $5.1 \mathrm{~g} / 100 \mathrm{~g}$ were reported in five Mexican varieties of black bean [26], other common bean varieties shows RS level of $5.4 \mathrm{~g} / 100 \mathrm{~g}$ (Peruano) [30], $5.3 \mathrm{~g} / 100 \mathrm{~g}$ (Cotaxtla) [13] and $0.64 \mathrm{~g} / 100 \mathrm{~g}$ (Mayocoba) [31]. QPM masa showed the lowest RS content, and an increase was obtained in tortilla (Table 2). Rendon-Villalobos et al. [19] reported similar pattern, with lower RS value in masa $(2.05 \mathrm{~g} / 100 \mathrm{~g})$ than tortilla $(3.12 \mathrm{~g} / 100 \mathrm{~g})$. The RS content of the QPM tortilla is higher than those reported in tortilla made with commercial dry masa flour (1.20-2.46 g/100 g) [25], tortilla made with commercial masas (1.36-3.05 g/100 g) [21], commercial tortilla (2.14 g/100 g) [13] and tortilla made with commercial white maize flour $(2.55 \mathrm{~g} / 100 \mathrm{~g})$ [16]. The QPM variety could be responsible of this high RS content in tortilla, because until today there are not reports dealing with RS content in this kind of tortilla. The addition of bean to maize produced a small increase in RS amount in tortilla because the value of QPM tortilla was high. Sáyago-Ayerdi et al. [13] reported in a Mexican "taco" (a mixture of tortilla and bean 60:40) a RS content of $3.93 \mathrm{~g} / 100 \mathrm{~g}$, and Hernández-Salazar et al. [16] in a commercial maize-bean tortilla a RS amount of $2.99 \mathrm{~g} / 100 \mathrm{~g}$. QPM-black bean tortilla has this characteristic that is important in health because recently has been considered the RS a functional ingredient to battle obesity [32].

\subsection{In Vitro Kinetic of Starch Digestion}

Figure 1 shows in vitro starch hydrolysis of QPM-black bean and QPM tortillas. QPM tortilla exhibited the highest hydrolysis percentage during the assay; its amylolysis level increased quickly (inside the first $15 \mathrm{~min}$ ), and thereafter the increase was slowest reaching approximately $55 \%$ after $30 \mathrm{~min}$ and did not increase at longer reaction times. Tortillas made with diverse commercial dry "masa" flours had similar pattern, but their levels of hydrolysis by the end of the assay had between $70-80 \%$ [25], and for tortillas made with diverse commercial "masas" the hydrolysis percentage were between $70-75 \%$ after $30 \mathrm{~min}$ of the assay and did not increase thereafter [21]. The lowest hydrolysis percentage in QPM tortilla can be due to that introduction of QPM character in maize modifies some 
structural characteristics of starch. A similar pattern to that of tortilla in the hydrolysis assay was found for QPM-black bean tortilla, but the hydrolysis percentage were lower, reaching at approximately $45 \%$ of hydrolysis after $30 \mathrm{~min}$. The addition of the bean to maize decrease the hydrolysis rate of starch present in the blend due to that bean had the lowest hydrolysis values, reaching to hydrolysis percentage at $90 \mathrm{~min}$ of approximately 11\%. Vargas-Torres et al. [26] reported hydrolysis percentage (90 min) for diverse cooked black bean varieties harvested in Mexico between 17 and 28\%. Tovar et al. [33] reported that several factors are involved in the reduced bioavailability of legume starches. The presence of intact tissue/cell structures enclosing starch granules hinders the swelling and solubilization of starch resulting in reduced in vitro digestion rate.

Figure 1. Average in vitro starch hydrolysis curves of black bean flour (*.), quality protein maize (QPM) tortilla (-) and QPM-black bean tortilla (- -). Bars represent SEM.

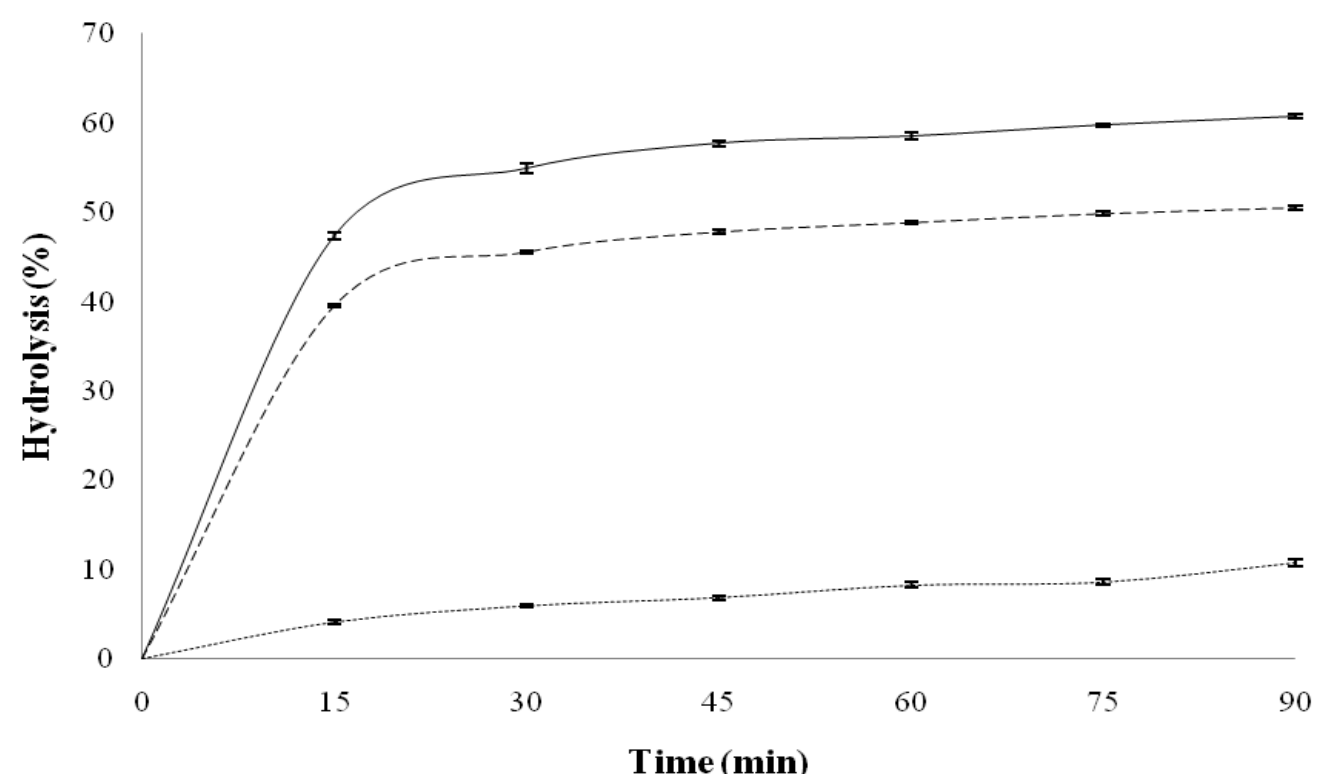

Predicted glycemic indices (pGI) were calculated from the 90 min degree of hydrolysis values of the samples (Table 3) [34]. QPM tortilla had the highest pGI compared to the rest of samples analyzed; however, this value is lower than those determined different tortillas, where the values ranged between 102 and 108 [35], and commercial tortilla was 97.5 [36]. QPM tortilla has been shown starch digestibility parameters lower than those determined in tortillas made with commercial dry masa flours, commercial masas and commercial tortillas, the use of QPM can be important to produce tortilla with low caloric response. Cooked black bean had the lowest pGI (47.9), but using other method (chewing/dialysis test) cooked black bean had lower pGI (27) [13], and using canned black bean with chewing/dialysis method the pGI value was 44 [14]. The addition of bean decreased the pGI value of tortilla (79.8) that was higher than those determined by the chewing/dialysis method in Mexican "taco" (a mixture of tortilla and bean 60:40), using different tortilla and bean, with value of 48 (tortilla and canned black bean) [14] and 51 (tortilla and cooked black bean) [13]. 
Table 3. Predicted glycemic index (pGI) of black bean flour, quality protein maize (QPM) tortilla and QPM-bVlack bean tortilla.

\begin{tabular}{ccc}
\hline Sample & Hydrolysis at 90 min (\%) & pGI $^{*}$ \\
\hline Black bean flour & $10.77 \pm 0.35 \mathrm{a}$ & $47.92 \pm 0.27 \mathrm{a}$ \\
QPM tortilla & $60.72 \pm 0.27 \mathrm{~b}$ & $87.97 \pm 0.22 \mathrm{~b}$ \\
QPM-black bean tortilla & $50.50 \pm 0.23 \mathrm{c}$ & $79.76 \pm 0.18 \mathrm{c}$ \\
\hline
\end{tabular}

Values are mean \pm SEM, $n=3$, dry matter. Means in the same column with different letter are significantly different $(\mathrm{p}<0.05)$. "Predicted glycemic index $(\mathrm{pGI})=39.21+0.803\left(\mathrm{H}_{90}\right)$ [34].

\subsection{Polyphenols Content}

Polyphenols content of raw materials and tortillas is shown in Table 4. Black bean presented the highest extractable polyphenols (EP) level. Two black bean varieties showed a phenolic content of 3.37 and $6.99 \mathrm{mg} / \mathrm{g}$, differences that can be attributed to the bean variety [37], a value within this range was determined here. EP value in tortilla was similar to those reported for yellow maize [38] with a free phenol content of $1.04 \mathrm{mg} / \mathrm{g}$ and cereals with a EP content of $1.07 \mathrm{mg} / \mathrm{g}$ [39]. The addition of bean to the blend increased the EP content in the tortilla in $107 \%$.

Table 4. Polyphenols content of black bean flour, quality protein maize (QPM) tortilla and QPM-black bean tortilla.

\begin{tabular}{cccc}
\hline \multirow{2}{*}{ Sample } & \multicolumn{3}{c}{ Polyphenols content $(\mathbf{m g} / \mathbf{g})$} \\
\cline { 2 - 4 } & EP & PA & HP \\
\hline Black bean flour & $5.55 \pm 0.08 \mathrm{a}$ & $22.94 \pm 2.12 \mathrm{a}$ & $12.13 \pm 0.23 \mathrm{a}$ \\
QPM tortilla & $0.96 \pm 0.05 \mathrm{~b}$ & N.d. & $5.70 \pm 0.13 \mathrm{~b}$ \\
QPM-black bean tortilla & $1.99 \pm 0.08 \mathrm{c}$ & $8.68 \pm 1.28 \mathrm{~b}$ & $6.17 \pm 0.18 \mathrm{~b}$ \\
\hline
\end{tabular}

Values are mean \pm SEM, $n=3$, dry matter. Means in the same column with different letter are significantly different $(\mathrm{p}<0.05)$. EP: Extractable polyphenols; PA: Proanthocyanidins; HP: Hydrolysable polyphenols; N.d.: Not detected.

Non extractable polyphenols (proanthocyanidins and hydrolysable polyphenols) in all samples showed higher value than extractable polyphenols, which is consistent with the results reported by Saura-Calixto et al. [39] for legumes and cereals.

It has been reported a wide range of proanthocyanidins (PA) content values in different bean varieties (16.8-38.1 mg/g [40]; 6.9-32.4 mg/g [41], the differences of PA content in beans depend on the variety and the locality [40], a value within these ranges was determined here. The PA in tortilla was not detected, as was reported by Pérez-Jiménez and Saura-Calixto [42] and Saura-Calixto et al. [39] for cereals. The PA was detected in tortilla added with bean; this behaviour indicates that the legume portion in tortilla plays an important role in the content of this kind of nutraceutical compounds.

Hydrolysable polyphenols (HP) comprise hydrolysable tannins, phenolic acids, and hydroxycinnamic acids that are released from the food matrix by strong acid hydrolysis, no proanthocyanidins or flavonoids are detected in the hydrolysates of hydrolysable polyphenols analysis [39]. Saura-Calixto et al. [39] reported a HP content of $5.93 \mathrm{mg} / \mathrm{g}$ for legumes (35\% chickpeas, $31 \%$ beans and $34 \%$ lentils), a value lower than that assessed here for black bean, this difference can be due to that different cultivar was 
studied. HP content of QPM tortilla was higher that those reported in yellow maize $(4.47 \mathrm{mg} / \mathrm{g})$ [38], the maize variety can be responsible of this difference, the value determined here is also higher that those reported in cereals (rice and wheat products) $(4.72 \mathrm{mg} / \mathrm{g})$ [39]. No difference in HP content was found between tortilla and black bean tortilla. Double cooking of bean could be responsible for this pattern, it has been reported that HP can be degraded by thermal action at high temperatures [43].

In general, total phenolic content (extractable and non-extractable polyphenols) in black bean tortilla was higher than the phenolic content of foods considered rich in polyphenols such as pepper (13.45 mg/g), broccoli (12.04 mg/g) and spinach (12.75 mg/g) [44].

\subsection{Antioxidant Capacity}

The antioxidant capacity (AC) of raw materials and tortillas is shown in Table 5. Extractable polyphenols of bean presented the highest AC level. Two black bean varieties showed an AC of 48.91 and $92.73 \mu \mathrm{mol}$ Trolox eq/g, the bean variety is responsible of this difference [37]. The AC of EP of tortilla was similar to those reported for vegetables $(6.7 \mu \mathrm{mol}$ Trolox eq $/ \mathrm{g})$ [45]. An increase of $80.5 \%$ in antioxidant capacity of EP in black bean tortilla was found compared with tortilla. The AC of EP of black bean tortilla was similar to those reported for products with high AC such as red wine (12.14 $\mu$ mol Trolox eq/ mL) [46].

Table 5. Antioxidant capacity of black bean flour, quality protein maize (QPM) tortilla and QPM-black bean tortilla.

\begin{tabular}{cccc}
\hline \multirow{2}{*}{ Sample } & \multicolumn{3}{c}{$\begin{array}{c}\text { Antioxidant capacity (ABTS method) } \\
(\boldsymbol{\mu m o l ~ T r o l o x ~ e q} / \mathbf{g})\end{array}$} \\
\cline { 2 - 4 } & $\mathbf{E P}$ & PA & HP \\
\hline Black bean flour & $57.58 \pm 0.18 \mathrm{a}$ & $11.27 \pm 0.65 \mathrm{a}$ & $14.54 \pm 0.24 \mathrm{a}$ \\
QPM tortilla & $6.95 \pm 0.49 \mathrm{~b}$ & N.d. & $0.87 \pm 0.46 \mathrm{~b}$ \\
QPM-black bean tortilla & $12.55 \pm 0.42 \mathrm{c}$ & $3.62 \pm 0.23 \mathrm{~b}$ & $1.44 \pm 0.35 \mathrm{~b}$ \\
\hline
\end{tabular}

Values are mean \pm SEM, $n=3$, dry matter. Means in the same column with different letter are significantly different $(\mathrm{p}<0.05)$. EP: Extractable polyphenols; PA: Proanthocyanidins; HP: Hydrolysable polyphenols; N.d.: Not detected.

The PA content in black bean was higher than EP content; however, the PA showed a lower antioxidant capacity, which could be due to differences in the chemical structures. The PA can be esterified with glucoside units in position C3 [47]. It has been observed that glycosylated flavonoids have minor antioxidant capacity [48]. Cooked black bean showed an antioxidant capacity of proanthocyanidins of $13.2 \mu \mathrm{mol}$ Trolox eq/g [12], a value higher than that assessed here, the variety of the bean and the method of determination can be responsible of this difference. The AC of PA was not detected in tortilla. A similar result was reported by Pérez-Jiménez and Saura-Calixto [42] for cereals. In black bean tortilla, the AC of PA was detected, this is due to a dilution effect when the bean was mixed with maize, the value was similar that those reported for asparagus ( $3.92 \mu \mathrm{mol}$ Trolox eq/g) and swiss chard stalk $(3.53 \mu \mathrm{mol}$ Trolox eq/g), the consumption of vegetables has been inversely associated with mortality from degenerative diseases [46]. 
No difference in AC of HP was found in tortilla and black bean tortilla. This pattern could be because HP in bean was degraded by thermal action in the second cooking [43].

In general, AC of total phenolic content (extractable and non-extractable polyphenols) in black bean tortilla was $17.61 \mu \mathrm{mol}$ Trolox eq/g; if tortilla consumption is $328 \mathrm{~g} /$ day [3], the AC provided by black bean tortilla is equivalent to $3.56 \mathrm{mmol}$ Trolox eq/day. Green tea is considered an important source of $\mathrm{AC}$, and the $\mathrm{AC}$ of green tea is $6.01 \mathrm{mmol}$ Trolox eq/L [46]. To reduce the risk to develop hypertension consumption of $120 \mathrm{~mL} /$ day of green tea (equivalent to $0.72 \mathrm{mmol}$ Trolox eq/day) is suggested [49]. Consumption of $10 \mathrm{cups} /$ day $(150 \mathrm{~mL} / \mathrm{cup}, 9.02 \mathrm{mmol}$ Trolox eq/day) is linked with a decreased relative risk of death from cardiovascular disease [50]. It has been reported that polyphenols have anticancer [51] and antiproliferative [52] and antimutagenic activity [53].

\section{Experimental Section}

\subsection{Sample Preparation}

Black common bean seeds, cv. Negro 8025, were harvested in 2008 at the Bajio Experimental Station of the National Research Institute for Forestry, Agriculture and Livestock (INIFAP), located in Celaya, Guanajuato, Mexico. Seeds of cv. Ancho QPM maize were harvested in 2009 at the INIFAP, located in Iguala, Guerrero, Mexico. After dry bean Negro 8025 were cooked in water with $\mathrm{NaCl}$ ( $10 \mathrm{~g} / \mathrm{Kg}$ bean) for $85 \mathrm{~min}$ at $97^{\circ} \mathrm{C}$, the grains and the cooking broth were lyophilized and then ground using a commercial grinder (Mapisa Internacional S.A. de C.V., Mexico, D.F.) to pass a US No. 50 sieve to produce the black bean flour. QPM maize grains were cooked in water $(1: 3, \mathrm{w} / \mathrm{v})$ for $30 \mathrm{~min}$ at $97{ }^{\circ} \mathrm{C}$ at alkaline $\mathrm{pH}$ using lime $(10 \mathrm{~g} / \mathrm{Kg}$ grain), followed by cooling and soaking for $12 \mathrm{~h}$. After soaking, QPM grains were washed three times with water, and grounded to make "masa" (QPM "masa"). Tortillas without cooked dry bean (QPM Tortilla) were produced with QPM "masa". QPM "masa" was blended with black bean flour to produce a 70:30 ratio (w/w, dry matter) followed by addition of water to form "masa" with the consistency to made tortillas (QPM-black bean tortilla). The relationship masa:black bean was obtained of previous studies [13-15]. "Masa" was molded by pressure and extruded in commercial tortilladora MOT-G model (Tortilladoras González, Naucalpan, México) into thin circles to obtain $2 \mathrm{~mm}$ thick tortillas. Tortillas were cooked on a hot griddle for 1 min per side at an approximate temperature of $250 \pm 5{ }^{\circ} \mathrm{C}$. QPM "masa", QPM tortilla and QPM-black bean tortilla were lyophilized and ground using a commercial grinder Universal model (Mapisa Internacional S.A. de C.V., Mexico, D.F.) to pass a US No. 50 sieve. The samples were stored at $10{ }^{\circ} \mathrm{C}$ until analysis.

\subsection{Chemical Analysis}

Ash, protein $(\mathrm{N} \times 6.25)$ and fat were assessed according to AACC methods $08-01,46-13$ and 30-25, respectively [54,55]. Total dietary fiber was determined following the AOAC method 985.29 [55]. All analyses were performed in triplicate. 


\subsection{Total Starch}

Total starch (TS) was determined by the method of Goñi et al. [34] with minor modifications; in brief, $50 \mathrm{mg}$ of sample were dispersed in $2 \mathrm{M} \mathrm{KOH}(60 \mathrm{~min})$ to disperse all starch fractions, then samples were incubated with amyloglucosidase (No. 10102857 001, Roche Diagnostics GmbH, Mannheim, Germany) at $60{ }^{\circ} \mathrm{C}$ and $\mathrm{pH} 4.75$ for $90 \mathrm{~min}$; glucose was determined using the glucose oxidase assay GOD-POD. TS were calculated as released glucose $(\mathrm{mg}) \times 0.9$.

\subsection{Resistant Starch}

Resistant starch (RS), including RS1 and RS2 fractions, was measured by Goñi et al. [56] in brief, protein and digestible starch were removal with pepsin (P-7000, Sigma Chemical Co., St. Louis, MO, USA) incubation $\left(40{ }^{\circ} \mathrm{C}, \mathrm{pH} 1.5,1 \mathrm{~h}\right)$ and $\alpha$-amylase (A-3176, Sigma Chemical Co.) incubation $\left(37^{\circ} \mathrm{C}\right.$, $\mathrm{pH} 6.9,16 \mathrm{~h})$. The residue was treated with $2 \mathrm{M} \mathrm{KOH}(30 \mathrm{~min})$ and then incubated with amyloglucosidase (No. 10102857 001, Roche Diagnostics $\mathrm{GmbH}$ ) at $60{ }^{\circ} \mathrm{C}$ and $\mathrm{pH} 4.75$ for $45 \mathrm{~min}$. Glucose was determined using glucose oxidase/peroxidase assay (GPSL-0507, Elitech Clinical Systems). RS was calculated as glucose $(\mathrm{mg}) \times 0.9$. Digestible starch was calculated by difference between TS and RS.

\subsection{In Vitro Kinetic of Starch Digestion}

The in vitro rate of hydrolysis was measured using hog pancreatic $\alpha$-amylase according to Holm et al. [57] with minor modifications. A $50 \mathrm{~mL}$ of phosphate buffer ( $\mathrm{pH} \mathrm{6.9)}$ were added to a portion of each sample containing $500 \mathrm{mg}$ of available starch. Samples were incubated a $37{ }^{\circ} \mathrm{C}$ in a shaking water bath. In the first $5 \mathrm{~min}$ before the addition of enzyme aliquots of $0.2 \mathrm{~mL}$ of each sample were taken to mark as time zero. After an interval of $1 \mathrm{~min}, 1 \mathrm{~mL}$ of a solution containing $40 \mathrm{mg}$ of porcine pancreatic $\alpha$-amylase (A-3176, Sigma Chemical Co.) in $1 \mathrm{~mL}$ of phosphate buffer was added to each sample. Samples $(0.2 \mathrm{~mL})$ were withdrawn after $15 \mathrm{~min}$ and every $15 \mathrm{~min}$ for $90 \mathrm{~min}$. These samples were added to tubes than containing $0.8 \mathrm{~mL}$ distilled water and $1 \mathrm{~mL}$ of 3,5 dinitrosalicylic acid (DNS). Samples were incubated at $100{ }^{\circ} \mathrm{C}$ in water bath for $10 \mathrm{~min}$. Then $15 \mathrm{~mL}$ of distilled water was added to each tube and mixed well. The reducing sugars released were measured at $530 \mathrm{~nm}$ in parallel with a standard curve of maltose. The rate of hydrolysis was expressed as the percentage of starch hydrolyzed with respect to dry matter at different times.

The predicted glycemic index (pGI) was calculated from percentage of starch hydrolyzed at $90 \mathrm{~min}$ $\left(\mathrm{H}_{90}\right)$ values using the formula proposed by Goñi et al. [34]: pGI $=39.21+0.803\left(\mathrm{H}_{90}\right)(r=0.909$, $p \leq 0.05)$.

\subsection{Determination of Polyphenols Content}

\subsubsection{Extractable Polyphenols}

Samples $(0.5 \mathrm{~g})$ were extracted by constant shaking at room temperature with methanol:water acidified with $\mathrm{HCl}(50: 50 \mathrm{v} / \mathrm{v}, \mathrm{pH} 2,50 \mathrm{~mL} / \mathrm{g}$ sample, $60 \mathrm{~min})$ and acetone:water $(70: 30 \mathrm{v} / \mathrm{v}, 50 \mathrm{~mL} / \mathrm{g}$ sample, $60 \mathrm{~min})$. After each extraction step, samples were centrifuged $\left(15 \mathrm{~min}, 25{ }^{\circ} \mathrm{C}, 3000 \mathrm{~g}\right)$ and 
supernatants were combined and used to determine extractable polyphenols content by the Folin-Ciocalteau procedure [58]. The results were expressed as gallic acid equivalents.

\subsubsection{Non Extractable Polyphenols}

\subsubsection{Proanthocyanidins}

Residues from the methanol/acetone/water extraction were treated with $5 \mathrm{~mL} / \mathrm{L} \mathrm{HCl}$ in butanol for $3 \mathrm{~h}$ at $100{ }^{\circ} \mathrm{C}$ for proanthocyanidins determination [59]. Proanthocyanidins were calculated from the absorbance at $550 \mathrm{~nm}$ of the anthocyanidin solutions. Proanthocyanidins from Mediterranean carob pod (Ceratonia siliqua L.) supplied by Nestlé S.A. were treated under the same conditions to obtain standard curves.

\subsubsection{Hydrolysable Polyphenols}

Hydrolysable polyphenols were determined by a methanol $/ \mathrm{H}_{2} \mathrm{SO}_{4} 90: 10(\mathrm{v} / \mathrm{v})$ hydrolysis at $85{ }^{\circ} \mathrm{C}$ for $20 \mathrm{~h}$ on the residues of the methanol/acetone/water extraction [60]. After centrifugation (15 min, $25{ }^{\circ} \mathrm{C}, 3000 \mathrm{~g}$ ) supernatants were used to determine hydrolysable polyphenols by the Folin-Ciocalteau procedure [58]. The results were expressed as gallic acid equivalents.

\subsection{Free Radical-Scavenging Assay (ABTS)}

The antioxidant capacity of extractable polyphenols, proanthocyanidins, and hydrolysable polyphenols extracted from samples were estimated in terms of radical-scavenging activity following the procedure described elsewhere [61] with some modification [62]. Briefly, ABTS [2,2'-azinobis-(3-ethyl-benzothiazoline-6-sulfonic acid)] radical cation (ABTS ${ }^{+}$) was produced by reacting $7 \mathrm{mM}$ ABTS stock solution with $2.45 \mathrm{mM}$ potassium persulphate in the dark at room temperature for $12-16 \mathrm{~h}$ before use. The $\mathrm{ABTS}^{+\bullet}$ solution was diluted with methanol to an absorbance of $0.70 \pm 0.02$ at $730 \mathrm{~nm}$. After addition of $0.1 \mathrm{~mL}$ of extract to $3.9 \mathrm{~mL}$ of diluted $\mathrm{ABTS}^{+\bullet}$ solution, absorbance readings were taken every $20 \mathrm{~s}$ using a UV-1800 UV-vis spectrophotometer (Shimadzu Europe $\mathrm{GmbH}$, Duisburg, Germany). The reaction was monitored for 6 min. Inhibition of absorbance versus time was plotted, and the area below the curve (0-6 min) was calculated. Results were expressed as $\mu \mathrm{mol}$ of Trolox equivalents per $\mathrm{g}$ of dry matter.

\subsection{Statistical Analysis}

Results are presented as mean \pm SEM (standard error of mean) of three separate determinations. A commercial software program (SigmaPlot for Windows version 11.0, San Jose, CA, USA) was used to evaluate, by one-way analysis of variance, significant differences in the means of measured parameters. Statistically significant differences $(p<0.05)$ amongst means were evaluated using the Tukey multiple comparison procedure. 


\section{Conclusions}

The addition of bean to tortilla made with quality protein maize improved the protein, ash and dietary fiber content. The starch digestibility rate of tortilla with bean decreased and, in consequence, produced lower predicted glycemic index. QPM Tortilla with black dry bean showed higher antioxidant capacity than QPM tortilla. The tortilla with bean can be an alternative for people with particular nutritional or metabolic requirements.

\section{Acknowledgments}

We appreciate the financial support from SIP-IPN, COFAA-IPN and EDI-IPN. One of the authors (E.M.G.-G.) also acknowledges the scholarship from CONACYT-México.

\section{References}

1. Paredes-López, O.; Saharopulos-Paredes, M.E. A review of tortilla production technology. Bakers Dig. 1983, 13, 16-25.

2. Robles, R.R.; Murray, E.D.; Paredes-López, O. Physicochemical changes of maize starch during the lime-heat treatment for tortilla making. Int. J. Food Sci. Technol. 1988, 23, 91-98.

3. Amaya-Guerra, C.A.; Alanis-Guzman, M.G.; Serna-Saldívar, S.O. Effects of soybean fortification on protein quality of tortilla-based diets produced from regular and quality protein maize. Plant Foods Hum. Nutr. 2004, 59, 45-50.

4. Serna-Saldívar, S.O.; Rooney, L.W. Quality protein maize processing and perspectives for industrial utilization. In Proceedings of the International Symposium on Quality Protein Maize, Sete Lagoas, MG, Brazil, 1-3 December 1994.

5. Sathe, S.R.; Rangnekar, P.D.; Deshpande, S.S.; Salunkhe, D.K. Isolation and partial characterization of black gram (Phaseolus mungo L.) starch. J. Food Sci. 1982, 47, 1524-1538.

6. Bourges, R.H. Las leguminosas en la alimentación. II Parte. Cuad. Nutr. 1987, 10, 22-30.

7. Reyes-Moreno, C.; Paredes-López, O. Hard to cook phenomenon in common beans-A review. Crit. Rev. Food Sci. Nutr. 1993, 33, 227-286.

8. Paredes-López, O.; Guzmán-Maldonado, S.H.; Serna-Saldívar, S.O. Los alimentos Mágicos de las Culturas Indígenas de México-El Caso de la Tortilla; Colegio de Sinaloa: Culiacán, Sinaloa, México, 2000.

9. Rosado, J.L.; López, P.; Morales, M.; Muñoz, E.; Allen, L.H. Bioavailability of energy, nitrogen, fat, zinc, iron and calcium from rural and urban Mexican diets. Br. J. Nutr. 1992, 68, 45-58.

10. Rehman, Z.; Salariya, A.M.; Zafar, S.I. Effect of processing on available carbohydrate content and starch digestibility of kidney beans (Phaseolus vulgaris L.). Food Chem. 2001, 73, 351-355.

11. Foster-Powell, K.; Brand-Miller, J. International tables of glycemic index. Am. J. Clin. Nutr. 1995, 62, 871S-893S.

12. Hernández-Salazar, M.; Osorio-Diaz, P.; Loarca-Piña, G.; Reynoso-Camacho, R.; Tovar, J.; Bello-Pérez, L.A. In vitro fermentability and antioxidant capacity of the indigestible fraction of cooked black beans (Phaseolus vulgaris L.), lentils (Lens culinaris L.) and chickpeas (Cicer arietinum L.). J. Sci. Food Agric. 2010, 90, 1417-1422. 
13. Sáyago-Ayerdi, S.G.; Tovar, J.; Osorio-Diaz, P.; Paredes-López, O.; Bello-Pérez, L.A. In vitro starch digestibility and predicted glycemic index of corn tortilla, black beans, and tortilla-bean mixture: Effect of cold storage. J. Agric. Food Chem. 2005, 53, 1281-1285.

14. Tovar, J.; Sáyago-Ayerdi, S.G.; Peñalver, C.; Paredes-López, O.; Bello-Pérez, L.A. In vitro starch hydrolysis index and predicted glycemic index of corn tortilla, black beans (Phaseolus vulgaris L.), and Mexican "taco". Cereal Chem. 2003, 80, 533-535.

15. Mora-Avilés, A.; Lemus-Flores, B.; Miranda-López, R.; Hernández-López, D.; Pons-Hernández, J.L.; Acosta-Gallegos, J.A.; Guzmán-Maldonado, S.H. Effects of common bean enrichment on nutritional quality of tortillas produced from nixtamalized regular and quality protein maize flours. J. Sci. Food Agric. 2007, 87, 880-886.

16. Hernández-Salazar, M.; Agama-Acevedo, E.; Sáyago-Ayerdi, S.G.; Tovar, J.; Bello-Pérez, L.A. Chemical composition and starch digestibility of tortillas prepared with non-conventional comercial nixtamalized maize flours. Int. J. Food Sci. Nutr. 2006, 57, 143-150.

17. Vargas-Torres, A.; Osorio-Díaz, P.; Tovar, J.; Paredes-López, O.; Ruales, J.; Bello-Pérez, L.A. Chemical composition, starch bioavailability and indigestible fraction of common beans (Phaseolus vulgaris L.). Starch Stärke 2004, 56, 74-78.

18. Méndez-Montealvo, G.; Solorza-Feria, J.; Velázquez, V.M.; Gómez-Montiel, N.; Paredes-López, O.; Bello-Pérez, L.A. Composición química y caracterización calorimétrica de híbridos y variedades de maíz cultivadas en México. Agrociencia 2005, 39, 267-274.

19. Rendón-Villalobos, R.; Bello-Pérez, L.A.; Osorio-Díaz, P.; Tovar, J.; Paredes-López, O. Effect of storage time on in vitro digestibility and resistant starch content of nixtamal, masa, and tortilla. Cereal Chem. 2002, 79, 340-344.

20. Graham, G.G. Quality-protein maize with a high fat content as a weaning food. J. Pediatr. Gastroenterol. Nutr. 1993, 17, 139-144.

21. Agama-Acevedo, E.; Rendón-Villalobos, R.; Tovar, J.; Trejo-Estrada, S.R.; Bello-Pérez, L.A. Effect of storage time on in vitro digestion rate and resistant starch content of tortillas elaborated from commercial corn masas. Arch. Latinoam. Nutr. 2005, 55, 86-92.

22. Silva-Cristobal, L.; Osorio-Díaz, P.; Tovar, J.; Bello-Pérez, L.A. Chemical composition, carbohydrate digestibility, and antioxidant capacity of cooked black bean, chickpea, and lentil Mexican varieties. CyTA J. Food 2010, 8, 7-14.

23. Bednar, G.E.; Patil, A.R.; Murray, S.M.; Grieshop, C.M.; Merchen, N.R.; Fahey, G.C., Jr. Starch and fiber fractions in selected food and feed ingredients affect their small intestinal digestibility and fermentability and their large bowel fermentability in vitro in a canine model. J. Nutr. 2001, 131, 276-286.

24. Reynoso-Camacho, R.; Ríos-Ugalde, M.C.; Torres-Pacheco, I.; Acosta-Gallegos, J.A.; Palomino-Salinas, A.C.; Ramos-Gómez, M.; González-Jasso, E.; Guzmán-Maldonado, S.H. El consumo de frijol común (Phaseolus vulgaris L.) y su efecto sobre el cáncer de colon en ratas Sprague-Dawley. Agric. Téc. Méx. 2007, 33, 43-52.

25. Agama-Acevedo, E.; Rendón-Villalobos, R.; Tovar, J.; Paredes-López, O.; Islas-Hernández, J.J.; Bello-Pérez, L.A. In vitro starch digestibility changes during storage of maize flour tortillas. Nahrung 2004, 48, 38-42. 
26. Vargas-Torres, A.; Osorio-Díaz, P.; Islas-Hernández, J.J.; Tovar, J.; Paredes-López, O.; Bello-Pérez, L.A. Starch digestibility of five cooked black bean (Phaseolus vulgaris L.) varieties. J. Food Compos. Anal. 2004, 17, 605-612.

27. Osorio-Díaz, P.; Méndez-Montealvo, G.; Agama-Acevedo, E.; Islas-Hernández, J.J.; Sánchez-Muñoz, J.; Bello-Pérez, L.A. Biodisponibilidad del almidón en dos variedades comerciales de frijol (Phaseolus vulgaris L.) y en frijoles industrializados. Agrociencia 2003, 37, $565-573$.

28. Björck, I.; Granfeldt, Y.; Liljeberg, H.; Tovar, J.; Asp, N.G. Food properties affecting the digestion and absortion of carbohydrates. Am. J. Clin. Nutr. 1994, 59, 699S-705S.

29. Fredriksson, H.; Björck, I.; Andersson, R.; Liljeberg, H.; Silverio, J.; Eliasson, A.C.; Aman, P. Studies on $\alpha$-amylase degradation of retrograded starch gels from waxy maize and high-amylopectin potato. Carbohydr. Polym. 2000, 43, 81-87.

30. Landa-Habana, L.; Piña-Hernández, A.; Agama-Acevedo, E.; Tovar, J.; Bello-Pérez, L.A. Effect of cooking procedures and storage on starch bioavailability in common beans (Phaseolus vulgaris L.). Plant Foods Hum. Nutr. 2004, 59, 133-136.

31. Osorio-Díaz, P.; Tovar, J.; Paredes-López, O.; Acosta-Gallegos, J.A.; Bello-Pérez, L.A. Chemical composition and in vitro starch bioavailability of Phaseolus vulgaris (L) cv Mayocoba. J. Sci. Food Agric. 2005, 85, 499-504.

32. Hendrich, S. Battling obesity with resistant starch. Food Technol. 2010, 64, 22-30.

33. Tovar, J.; Björck, I.M.; Asp, N.G. Starch content and $\alpha$-amylolysis rate in precooked legume flours. J. Agric. Food Chem. 1990, 38, 1818-1823.

34. Goñi, I.; Garcia-Alonso, A.; Saura-Calixto, F. A starch hydrolysis procedure to estimate glycemic index. Nutr. Res. 1997, 17, 427-437.

35. Bello-Pérez, L.A.; Rendón-Villalobos, J.R.; Agama-Acevedo, E.; Islas-Hernández, J.J. In vitro starch digestibility of tortillas elaborated by different masa preparation procedures. Cereal Chem. 2006, 83, 188-193.

36. Hernández-Uribe, J.P.; Agama-Acevedo, E.; Islas-Hernández, J.J.; Tovar, J.; Bello-Pérez, L.A. Chemical composition and in vitro starch digestibility of pigmented corn tortilla. J. Sci. Food Agric. 2007, 87, 2482-2487.

37. Xu, B.J.; Yuan, S.H.; Chang, S.K.C. Comparative analyses of phenolic composition, antioxidant capacity, and color of cool season legumes and other selected food legumes. J. Food Sci. 2007, 72, S167-S177.

38. Lopez-Martinez, L.X.; Oliart-Ros, R.M.; Valerio-Alfaro, G.; Lee, C.-H.; Parkin, K.L.; Garcia, H.S. Antioxidant activity, phenolic compounds and anthocyanins content of eighteen strains of Mexican maize. LWT Food Sci. Technol. 2009, 42, 1187-1192.

39. Saura-Calixto, F.; Serrano, J.; Goñi, I. Intake and bioaccessibility of total polyphenols in a whole diet. Food Chem. 2007, 101, 492-501.

40. De Mejia, E.G.; Guzmán-Maldonado, S.H.; Acosta-Gallegos, J.A.; Reynoso-Camacho, R.; Ramírez-Rodríguez, E.; Pons-Hernández, J.L.; González-Chavira, M.M.; Castellanos, J.Z.; Kelly, J.D. Effect of cultivar and growing location on the trypsin inhibitors, tannins, and lectins of common beans (Phaseolus vulgaris L.) grown in the semiarid highlands of Mexico. J. Agric. Food Chem. 2003, 51, 5962-5966. 
41. Guzmán-Maldonado, H.S.; Castellanos, J.; González, M.E. Relationship between theoretical and experimentally detected tannin content of common beans (Phaseolus vulgaris L.). Food Chem. 1996, 55, 333-335.

42. Pérez-Jiménez, J.; Saura-Calixto, F. Literature data may underestimate the actual antioxidant capacity of cereals. J. Agric. Food Chem. 2005, 53, 5036-5040.

43. Maillard, M.-N.; Berset, C. Evolution of antioxidant activity during kilning: Role of insoluble bound phenolic acids of barley and malt. J. Agric. Food Chem. 1995, 43, 1789-1793.

44. Turkmen, N.; Sari, F.; Velioglu, Y.S. The effect of cooking methods on total phenolics and antioxidant activity of selected green vegetables. Food Chem. 2005, 93, 713-718.

45. Saura-Calixto, F.; Goñi, I. Antioxidant capacity of the spanish mediterranean diet. Food Chem. 2006, 94, 442-447.

46. Pellegrini, N.; Serafini, M.; Colombi, B.; Del Rio, D.; Salvatore, S.; Bianchi, M.; Brighenti, F. Total antioxidant capacity of plant foods, beverages and oils consumed in Italy assessed by three different in vitro assays. J. Nutr. 2003, 133, 2812-2819.

47. Dueñas, M.; Sun, B.; Hernández, T.; Estrella, I.; Spranger, M.I. Proanthocyanidin composition in the seed coat of lentils (Lens culinaris L.). J. Agric. Food Chem. 2003, 51, 7999-8004.

48. Plumb, G.W.; Prince, K.R.; Williamson, G. Antioxidant properties of flavonol glucosides from tea. Redox Report 1999, 4, 13-16.

49. Yang, Y.-C.; Lu, F.-H.; Wu, J.-S.; Wu, C.-H.; Chang, C.-J. The protective effect of habitual tea consumption on hypertension. Arch. Intern. Med. 2004, 164, 1534-1540.

50. Nakachi, K.; Matsuyama, S.; Miyake, S.; Suganuma, M.; Imai, K. Preventive effects of drinking green tea on cancer and cardiovascular disease: Epidemiological evidence for multiple targeting prevention. BioFactors 2000, 13, 49-54.

51. Jankun, J.; Selman, S.H.; Swiercz, R.; Skrzypczak-Jankun, E. Why drinking green tea could prevent cancer. Nature 1997, 387, 561.

52. Seeram, N.P.; Adams, L.S.; Hardy, M.L.; Heber, D. Total cranberry extract versus its phytochemical constituents: Antiproliferative and synergistic effects against human tumor cell lines. J. Agric. Food Chem. 2004, 52, 2512-2517.

53. Aparicio-Fernández, X.; Manzo-Bonilla, L.; Loarca-Piña, G.F. Comparison of antimutagenic activity of phenolic compounds in newly harvested and stored common beans phaseolus vulgaris against aflatoxin $\mathrm{B}_{1}$. J. Food Sci. 2005, 70, S73-S78.

54. AACC International Methods. Approved Methods of the American Association of Cereal Chemists, 10th ed.; International Press: St. Paul, MN, USA, 2000.

55. Official Methods of Analysis, 16th ed.; AOAC International: Gaithersburg, MD, USA, 1997.

56. Goñi, I.; García-Diz, L.; Mañas, E.; Saura-Calixto, F. Analysis of resistant starch: A method for foods and food products. Food Chem. 1996, 56, 445-449.

57. Holm, J.; Björck, I.; Asp, N.G.; Sjoberg, L.B.; Lundquist, I. Starch availability in vitro and in vivo after flaking, steam-cooking and popping of wheat. J. Cereal Sci. 1985, 3, 193-200.

58. Singleton, V.L.; Orthofer, R.; Lamuela-Raventós, R.M. Analysis of total phenols and other oxidation substrates and antioxidants by means of Folin-Ciocalteu reagent. Methods Enzymol. 1999, 299, 152-178. 
59. Reed, J.D.; Mcdowell, R.E.; van Soest, P.J.; Horvath, P.J. Condensed tannins: A factor limiting the use of cassava forage. J. Sci. Food Agric. 1982, 33, 213-220.

60. Hartzfeld, P.W.; Forkner, R.; Hunter, M.D.; Hagerman, A.E. Determination of hydrolizable tannins (gallotannins and ellagitanins) after reaction with potassium iodate. J. Agric. Food Chem. 2002, 50, 1785-1790.

61. Re, R.; Pellegrini, N.; Proteggente, A.; Pannala, A.; Yang, M.; Rice-Evans, C. Antioxidant activity applying an improved ABTS radical cation decolorization assay. Free Radic. Biol. Med. 1999, 26, 1231-1237.

62. Pulido, R.; Hernández-García, M.; Saura-Calixto, F. Contribution of beverages to the intake of lipophilic and hydrophilic antioxidants in the Spanish diet. Eur. J. Clin. Nutr. 2003, 57, 1275-1282.

(C) 2012 by the authors; licensee MDPI, Basel, Switzerland. This article is an open access article distributed under the terms and conditions of the Creative Commons Attribution license (http://creativecommons.org/licenses/by/3.0/). 